\title{
Study of photodynamic effects on NIH 3T3 cell line and bacteria
}

\author{
Adela Hanakovaa , Katerina Bogdanovab ${ }^{b}$ Katerina Tomankovaa , Svatopluk Bindera , Robert Bajgara , Katerina Langovaa, \\ Milan Kolar ${ }^{b}$, Jiri Mosingerc, Hana Kolarova ${ }^{a}$
}

Background. Bacterial resistance to antibiotics is a constantly growing challenge. Photodynamic therapy (PDT) offers a new approach to the treatment of bacterial and viral diseases. The aim of this study was to compare the efficacy of photosensitizers used in PDT applied to cell lines and bacterial strains.

Methods. We tested the cytotoxicity and phototoxicity of 3 photosensitizers: TPPS $_{4^{\prime}}$ ZnTPPS $_{4}$ and TMPyP applied to the NIH3T3 cell line using two established methods for measuring ROS production and, MTT viability assay. Bacterial viability was determined spectrophotometrically over $24 \mathrm{~h}$ following PDT.

Results. The most efficient photosensitiser was TMPyP as it reduced the viability of the NIH3T3 cell line by more than $85 \%$. In general, the photosensitisers were more phototoxic to the two Gram-positive bacterial strains, Enterococcus faecalis and Staphylococcus aureus. The viability of E. faecalis was reduced to $78 \%$ by a dose radiation $0.5 \mathrm{~J} / \mathrm{cm}^{2}$ and concentration of TMPyP $1.562 \mu \mathrm{mol} / \mathrm{L}$. The viability of bacterium S. aureus was reduced to $23 \%$ when exposed to a ra-

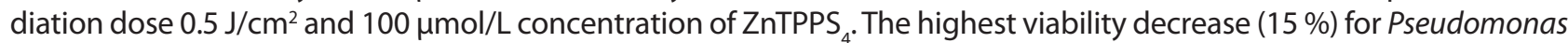
aeruginosa was caused by $0.5 \mathrm{~J} / \mathrm{cm}^{2}$ radiation dose and $50 \mu \mathrm{mol} / \mathrm{L}$ TMPyP concentration. Escherichia coli proved to be PDT resistant as the bacterial viability was higher than $90 \%$.

Conclusions. The goal of the present study was to test the efficiency of photosensitizers on the NIH $3 \mathrm{~T} 3$ cell line and bacterial cells. Subsequently we would like to study effectiveness of photosensitizers bound to carriers (for example cyclodextrins) on other cell line and bacterial strain.

Key words: phototoxicity, porphyrin, Gram-positive bacteria, Gram-negative bacteria, antibacterial therapy

Received: December 13, 2011; Accepted with revision: May 18, 2012; Available online: June 15, 2012 http://dx.doi.org/10.5507/bp.2012.057

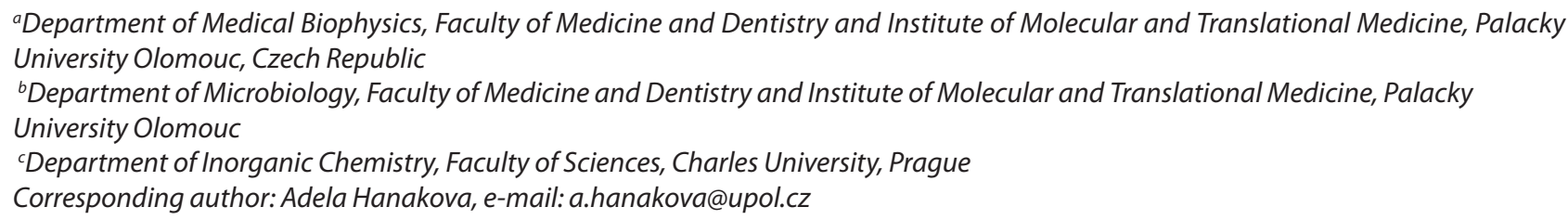

\section{INTRODUCTION}

Photodynamic therapy (PDT) is a relatively new modality for the treatment of illnesses. The first application of PDT research was successfully used in the treatment of cancer. Currently, it is being studied for its application to various other diseases such as cardiovascular disorders and antimicrobial therapy. PDT is now used as a treatment for localized microbial infections. From the time of the discovery of antibiotics in the last century, photodynamic therapy was abandoned. In recent decades however, the worldwide rise in antibiotic resistance has driven research to the development of new anti-microbial strategies. A number of human pathogens are increasingly resistant to antibiotics and the issue is still growing. PDT appears to be the new treatment for a number of microbial diseases. Studies confirm the differences in perception between Gram-positive and Gram-negative bacteria to PDT ( ref. $^{1-3}$ ). The main reason for the differential sensitivity and response to PDT is the varied structure of bacterial cells. Anionic and neutral photosensitizers are effective in the case of Gram-positive bacteria, inducing growth inhibition or killing by visible light whereas Gram-negative bacteria are not killed in this way. However, direct photokilling of Gram-negative bacteria is also possible. In recent years, a large number of chemical classes of positively charged photosensitizers, including porphyrins and phtalocyanines, have been successfully tested as photoinactivating agents against Gram-positive and Gram-negative bacteria ${ }^{4-7}$.

The phototoxicity of chemical compounds towards microorganisms was first published at the turn of the 20th century. Oskar Raab observed that the toxicity of acridine hydrochloride against Paramecia candatum was dependent on the amount of light ${ }^{8}$.

Another type of application of PDT is treatment of non-tumour diseases affecting the musculoskeletal system due to uncontrollable proliferation of synovial tissue cells, rheumatoid arthritis. This is an autoimmune disorder involving severe degenerative inflammation of the joints, and hyperproliferative growth of the synovial membrane into the synovial space. It limits the range of motion, as well as causing irreversible erosive damage of the joint by invasion of cartilagenous surfaces ${ }^{9}$. We used the fibroblastic NIH3T3 cell line as a tissue model to test the effectiveness of PDT. 
The first generation of PDT photosensitizers to win the approval of the regulatory agencies in several countries was Protofrin. This is a complex mixture of the more active porphyrin oligomers that comprises the hematoporphyrin derivate $(\mathrm{HpD})\left(\right.$ ref. $\left.^{10}\right)$. However, Protofrin has not been sufficient for all the criteria for an ideal photosensitizer, mainly due to its complexity and poor absorption of tissue-penetrating red light. $\mathrm{HpD}$ is also retained in the skin and thus characterization extended to produce cutaneous photosensitivity. The unsatisfactory features of the first generation photosensitizers stimulated development of a second generation photosensitizers. This includes: benzoporphyrins, porphyrins, purpurins, texaphyrins, pthalocyanines and endogenously generated photosensitive metabolites - protoporphyrin IX (PPIX). Currently, a third generation of photosensitizers represents an emerging class of compounds in the shape of second generation photosensitizer with the addition of carrier molecules to deliver photosensitizer to tumor tissue.

This alternative therapeutic approach employs nontoxic dye, photosensitizer, and visible light which, in the presence of oxygen, combine to produce cytotoxic oxygen species. Antimicrobial photodynamic therapy involves the killing of pathogenic cells by light in the presence of a photosensitizing agent. Excitation of the photosensitizer by absorption of light of appropriate wavelength converts the photosensitizer into its photoactive triple state. This in turn, reacts with either a local substrate (type I reaction) to form cytotoxic radicals or with molecular oxygen (type II reaction) to produce cytotoxic singlet oxygen $\left({ }^{1} \mathrm{O}_{2}\right)$ and free radicals ${ }^{11-13}$. The reactive oxygen species lead to cell death or initiate it.

We conducted an experiment with photosensitisers ZnTPPS $_{4}$, TPPS $_{4}$ and TMPyP, applied them to NIH 3T3 cells and compared the result with the bacterial strains. We focused on the efficacy of photodynamic therapy to diminish cell viability.

\section{MATERIAL AND METHODS}

\section{Photosensitisers}

We used 3 photosensitizers: TPPS ${ }_{4}$, ZnTPPS $_{4}$ and TMPyP, which were prepared by Jiri Mosinger at the Department of Inorganic Chemistry, Faculty of Sciences, Charles University in Prague, Prague, Czech Republic.

\section{Cell line}

The NIH 3T3 cells (Mouse embryonic fibroblast cell line, ATTC, USA) were grown in 96-well microplates ( $10^{4}$ cells/well), using cultivation medium DMEM with additions of $0.5,1,5,10,50$ and $100 \mu \mathrm{mol} / \mathrm{L}$ photosensitizers at $37{ }^{\circ} \mathrm{C}, 5 \% \mathrm{CO}$ for 24 hours in darkness. The viability of cell line was then investigated using methods for evaluating cell damage ${ }^{14}$.

\section{Irradiation}

To produce the photodynamic effect, we used light emitting diodes (LEDs $414 \mathrm{~nm}$ ) in a total dose of from 0.5 to $25 \mathrm{~J} / \mathrm{cm}^{2}$.

\section{Determination of ROS}

ROS are reactive oxygen species originating in mitochondria. When the cell diaphragmal (membrane) potential rises, respiration is low and the production of ROS increases. Production of ROS is an indicator of cell damage leading to cell death. The efficacy of photosensitizers to produce photoinactivation on bacterial strains was determined spectrophotometrically. The production of ROS in cells was investigated by molecular probe CM-H DCFDA (5-(and-6)-chloromethyl-2',7'-dichlorodihydrofluorescein diacetate, acetyl ester) (Invitrogen) which is sensitive enough to detect intracellular ROS. This agent is a derivative of DCF-DA. ROS measurement was performed using 5-(6-)-chloromethyl-2', 7'dichlorodihydrofluorescein diacetate (CM-H DCFDA) producing fluorescence dye $\mathrm{CM}-\mathrm{DCF}$ in the presence of ROS. DCF-DA has been used as a detector of ROS in many applications. This dye is not fluorescent in reduced chemical form but after cellular oxidation and withdrawal of acetate groups by cellular esterases it converts into fluorescent. After incubation with photosensitizers, cells were treated with $10 \mu \mathrm{mol} / \mathrm{L} \mathrm{CM}-\mathrm{H}_{2}$ DCFDA for $30 \mathrm{~min}$ at $37^{\circ} \mathrm{C}$ in darkness. Fluorescence of CM-DCF (excitation/ emission: 495/530 nm) was recorded by 96-well microplate reader Synergy HT (BioTek, Winooski, Vermont, USA) (ref. $\left.{ }^{14}\right)$. Fluorescence of CM-DCF was calibrated according to the corresponding fluorescence response of the probe to the addition of external $\mathrm{H}_{2} \mathrm{O}_{2}$ (ref. ${ }^{15}$ ). Two columns of wells were used as negative control (photodynamically treated cell line in the absence of photosensitizer). The experiment was repeated three times.

\section{Cell viability test}

Phototoxicity was evaluated by the MTT test. This colorimetric assay measures the reduction of yellow 3-(4,5-dimethythiazol-2-yl)-2,5-diphenyl-2H-tetrazolium bromide (MTT) by mitochondrial succinate dehydrogenase. MTT enters the cells and passes into the mitochondria where is reduced to an insoluble, purple formazan product. The crystals in the cells are then dissolved with an organic solvent. Since reduction of MTT can only occur in metabolically active cells, the level of activity is a measure of the viability of the cells. After photodynamic treatment, the cells were incubated at $37{ }^{\circ} \mathrm{C}, 5 \% \mathrm{CO}_{2}$ for $24 \mathrm{~h}$ in fresh DMEM. Before the start of the viability measurement, DMEM was replaced by $0.5 \mathrm{mg} \mathrm{ml}^{-1}$ MTT (Sigma-Aldrich) dissolved in PBS and incubated for $3.5 \mathrm{~h}$ at $37{ }^{\circ} \mathrm{C}$ and $5 \% \mathrm{CO}_{2}$ atmosphere. The MTT solution was then carefully removed and replaced with $100 \mu \mathrm{l}$ of DMSO to dissolve formazan crystals. The absorbance of the prepared solution was measured in 96-well microplate reader Synergy HT at $570 \mathrm{~nm}$ and $690 \mathrm{~nm}^{14}$. The experiment was repeated three times.

\section{Bacteria}

For our PDT study we used 2 Gram-positive bacteria strains: Staphylococcus aureus CCM 4223 (ATCC 29213) and Enterococcus faecalis CCM 4224 (ATCC 29212) and 2 Gram-negative strains: Escherichia coli CCM 3954 (ATCC 
25922) and Pseudomonas aeruginosa CCM 3955 (ATCC 27853). The bacteria were used at a density of $10^{6} \mathrm{cfu} / \mathrm{mL}$ and grown in Brain Heart Infusion (Himedia) in shaker BMT (Brněnská medicínská technika) aerobically at $37^{\circ} \mathrm{C}$ for $2 \mathrm{~h}$ in darkness.

Photodynamic inactivation of bacterial strains

Suspensions of bacteria $\left(10^{6} \mathrm{cfu} / \mathrm{mL}\right)$ were tested in 96-well microplates (GAMA GROUP a.s., Czech republic), where photosensitizers were diluted by geometric series (concentrations from 100 to $0.78128 \mu \mathrm{mol} / \mathrm{L}$ ). After $2 \mathrm{~h}$ in darkness, the bacterial culture appeared in the exponential growth phase. The microplates were irradiated from above by a light source (LEDs $414 \mathrm{~nm}$ ) 0.5 - $25 \mathrm{~J} /$ $\mathrm{cm}^{2}$ and after $24 \mathrm{~h}$ of culture incubation in darkness and aerobically at $37^{\circ} \mathrm{C}$, the absorbance was measured on a spectrophotometer (BioTek, Winooski, Vermont, USA) in program Gen 5 at a wavelength of $630 \mathrm{~nm}$. The experiments were repeated three times. Control samples were bacteria untreated with photosensitizers or light and bacteria exposed to light in the absence of photosensitizers.

\section{Statistical analysis}

The data were presented as mean \pm SD of three independent experiments. The statistical significance was determined by an analysis of variance with ANOVA. $P<0.05\left(^{*}\right)$ was considered statistically significant. If the ANOVA demonstrated for some quantities showed statistically significant differences, multiple comparison test of LSD (Least Significant Difference) was performed. If the value $P<0.05\left(^{*}\right)$, differences were statistically significant.

\section{RESULTS}

Cytotoxicity and phototoxicity determination of cell line NIH 3T3

Firstly, cell cytotoxicity of all photosensitizers were tested on NIH3T3 cell line. The cells were incubated with the tested photosensitizers for $24 \mathrm{~h}$ without irradiation and ROS production determination and MTT assay were performed. The viability of the cells inoculated with all tested compounds was reduced by only $10 \%$ which was confirmed by MTT assay. The highest relative fluorescence units and concentration of $\mathrm{H}_{2} \mathrm{O}_{2}$ were detected for TMPyP at a concentration $100 \mu \mathrm{mol} / \mathrm{L}$. Higher concentrations of photosensitizer can lead to cytotoxicities of their own ${ }^{16}$.

According to our results, the most efficient light dose to NIH $3 \mathrm{~T} 3$ cell line was from $0.5 \mathrm{~J} / \mathrm{cm}^{2}$ to $10 \mathrm{~J} / \mathrm{cm}^{2}$ and the concentration of TMPyP was from 0.5 to $100 \mu \mathrm{mol} / \mathrm{L}$ (Fig. 1, 2, 3). It was also demonstated that high phototoxicity was achieved at a light dose of $1 \mathrm{~J} / \mathrm{cm}^{2}$ and concentration of TMPyP $10 \mu \mathrm{mol} / \mathrm{L}$ (Table 1). In this regard, the viability of the cell line decreased to $13 \%$. However, the observed phototoxicity of TMPyP was higher than the phototoxicity of the other two photosensitizers. In order to determinate hydrogen peroxide values it was necessary to carry out calibration of the dependence of fluorescence on concentration of $\mathrm{H}_{2} \mathrm{O}_{2}$ (Table 2). From the graphs

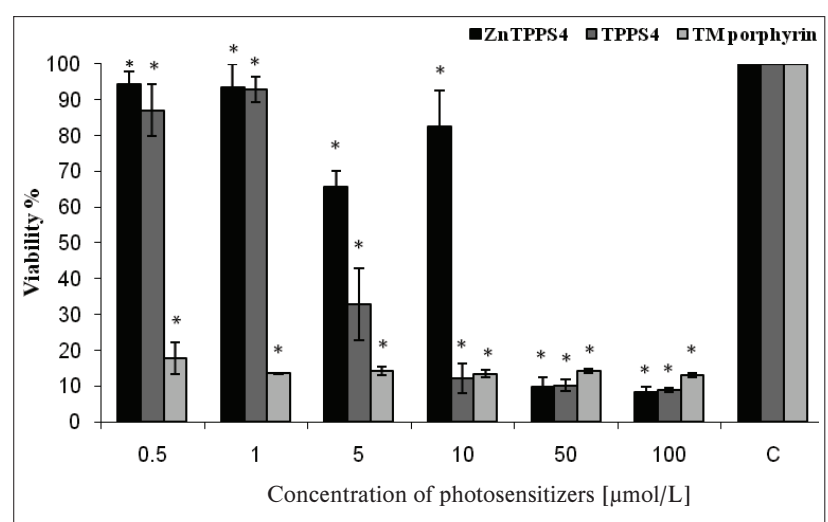

Fig. 1. Dependence of cell viability NIH 3 T3 on the photosensitizers concentration at light dose of $1 \mathrm{~J} / \mathrm{cm}^{2} ; \mathrm{C}$ - control plate (without photosensitizers).

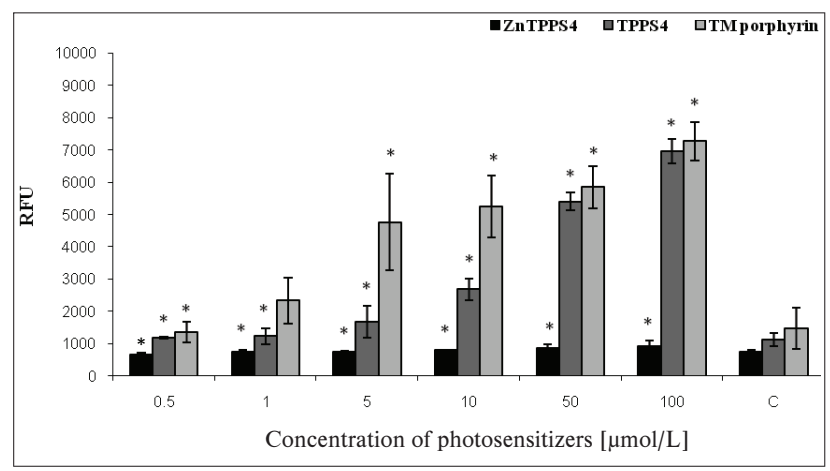

Fig. 2. Dependence of relative fluorescence unit of NIH 3T3 cell line on concentration of photosensitizers and light dose of $1 \mathrm{~J} / \mathrm{cm}^{2}$; RFU - Relative Fluorescence Unit; C - control plate (without photosensitizers).

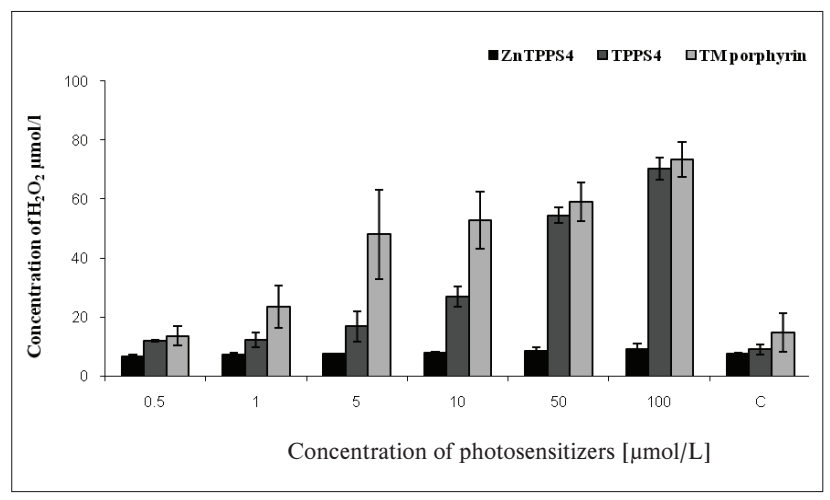

Fig. 3. Dependence of $\mathrm{H}_{2} \mathrm{O}_{2}$ production in NIH $3 \mathrm{~T} 3$ cell line on concentration of photosensitizers at light dose of $1 \mathrm{~J} / \mathrm{cm}^{2}$; C - control plate (without photosensitizers).

suggest that the photosensitizer TMPyP is very efficient on the NIH 3 T3 cell line. We can conclude that bacteria show higher resistance against applied photodynamic therapy. The phototoxicity of these photosensitizers is the subject of ongoing investigation along with other photosensitizers to be tested in conjunction with chemical carriers towards increase efficiency of antimicrobial photodynamic effect. 
(Fig. 2, 3) it is obvious that production of cytotoxic ROS is highest for photosensitizer TMPyP.

\section{Bacterial strains}

From these results (Fig. 4, 5, 6 and 7) it is also clear that PDT applied to strains of Gram-positive bacteria showed greater efficiency than to Gram-negative bacteria. For Pseudomonas aeruginosa we achieved the best results for concentrations of TMPyP 50, 25, 12.5 and $6.25 \mu \mathrm{mol} / \mathrm{L}$ and light dose of $0.5 \mathrm{~J} / \mathrm{cm}^{2}$ (Fig. 4), (Table 4). However, the viability of microorganism remained high $(85 \%)$. The viability of Gram-positive bacteria Enterococcus faecalis was lowest (78\%) at a light dose of $0.5 \mathrm{~J} / \mathrm{cm}^{2}$ and concentration of TMPyP $1.562 \mu \mathrm{mol} / \mathrm{L}$ (Fig. 5), (Table 5). We found that ZnTPPS appears to be an appropriate photosensitizer for PACT. Bacteria Staphylococcus aureus exposed to a radiation dose $0.5 \mathrm{~J} / \mathrm{cm}^{2}$ and concentration $100 \mu \mathrm{mol} / \mathrm{L}$ of $\mathrm{ZnTPPS}_{4}$ is represented by a decline in viability to $23 \%$ under these conditions (Fig. 6), (Table 3). Photosensitizer TMPyP was not so efficient, as the viability of bacteria decreased to $91 \%$ at a light dose of $0.5 \mathrm{~J} / \mathrm{cm}^{2}$ and concentration at $0.78128 \mu \mathrm{mol} / \mathrm{L}$. The photodynamic effect with the 3 tested photosensitizers was not evident for Escherichia coli (Fig. 7). Our development was performed to compare the photosensitivity and the antimicrobial effectivity of cell line NIH 3T3 and the pathogen microbial cell. The testing of the ability was focused on investigating the cytotoxic effect of photosensitizers and the decrease in viability of 4 bacterial strains. The concentration of TMPyP $1.562 \mu \mathrm{mol} / \mathrm{L}$ and light dose $0.5 \mathrm{~J} / \mathrm{cm}^{2}$ were efficient in the case of Gram-positive bacteria Enterococcus faecalis (Fig. 5). The most efficient photosensitizer for destroying Gram-positive bacteria $S$. aureus was $\mathrm{ZnTPPS}_{4}$ at a concentration of $100 \mu \mathrm{mol} / \mathrm{L}$ and light dose of $0.5 \mathrm{~J} / \mathrm{cm}^{2}$ while TMPyP was less efficient for use in antimicrobial photodynamic therapy (Fig. 6). On the other hand TMPyP was efficient at a concentration of $50 \mu \mathrm{mol} / \mathrm{L}$ and light dose of $0.5 \mathrm{~J} / \mathrm{cm}^{2}$ in the case of Gram-negative bacteria Pseudomonas aeruginosa (Fig. 4). The other Gram-negative bacteria strain Escherichia coli was not strongly sensitive to PDT with any of the 3 tested photosensitizers.

\section{DISCUSSION}

In this study, the cytotoxic effect of ZnTPPS $_{4}$, TPPS and TMPyP was tested on NIH 3T3 cells by MTT test and determination of ROS production. Our results show that ROS production and cell viability in NIH 3T3 cell line and bacterial strains are dependent on photosensitizer concentration and dose of irradiation. Although all tested photosensitizers were able to induce photodynamic effects, TMPyP was found to be the most efficient photosensitizer to the NIH 3T3 cell line. Fig. 1, 2 and 3 demonstrate the accumulation of fluorescence in cells corresponding to production of ROS and consequently decrease in viability. Based on our results with 4 bacte-

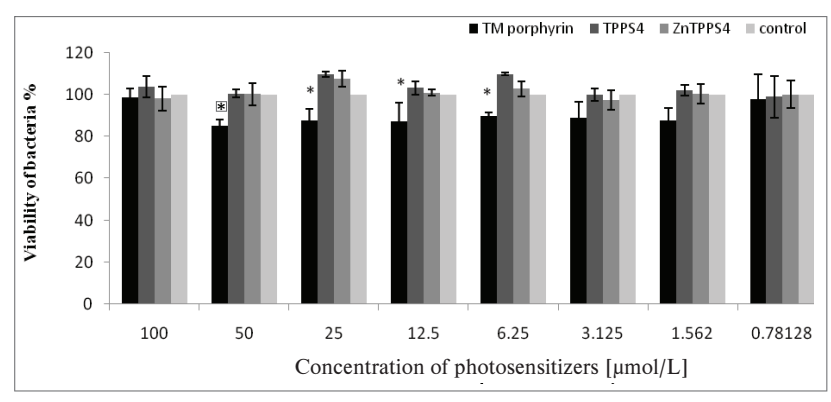

Fig. 4. Dependence of viability bacterial strain Pseudomonas aeruginosa on concentration of photosensitizers at light source of $0.5 \mathrm{~J} / \mathrm{cm}^{2}$.



Fig. 5. Dependence of viability bacterial strain Enterococcus faecalis on concentration of photosensitizers at light dose of $0.5 \mathrm{~J} / \mathrm{cm}^{2}$.

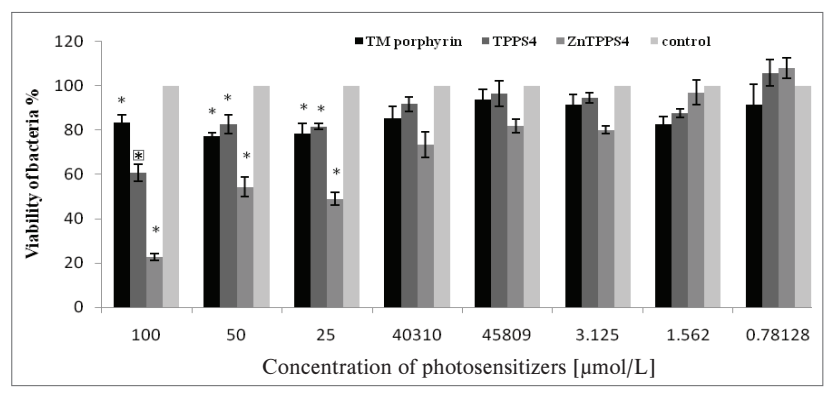

Fig. 6. Dependence of viability bacterial strain Staphylococcus aureus on concentration of photosensitizers at light dose of $0.5 \mathrm{~J} / \mathrm{cm}^{2}$.

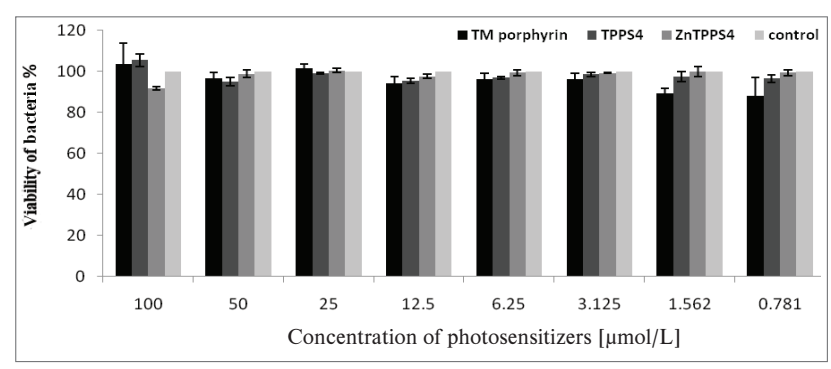

Fig. 7. Dependence of viability bacterial strain Escherichia coli on concentration of photosensitizers at light dose of $0.5 \mathrm{~J} / \mathrm{cm}^{2}$.

rial strains, we conclude that photosensitizers are more antimicrobial toward Gram-positive bacteria than to less photosensitizing Gram-negative bacteria. The structure and organization of the cell wall are the presumed cause 
Table 1. Statistics data for viability of cell line NIH3T3 after exposure light of dose $1 \mathrm{~J} / \mathrm{cm}^{2}$.

\begin{tabular}{lccc}
\hline Photosensitizers & Concentration $(\mu \mathrm{mol} / \mathrm{L})$ & F $($ ANOVA $)$ & Sig. $(P)$ \\
\hline Between TPPS & , ZnTPPS \\
, TMPyP & 10 & 206.939 & $<0.0001$ \\
\hline Photosensitizers & Concentration $(\mu \mathrm{mol} / \mathrm{L})$ & LSD Sig. $(P)$ & - \\
\hline TPPS $_{4}$ x ZnTPPS & & $<0.0001$ & \\
TPPS $_{4}$ x TMPyP & 10 & $<0.0001$ & - \\
TMPyP x ZnTPPS $_{4}$ & & $<0.0001$ & \\
\hline
\end{tabular}

F - test statistics; Sig. $(P)$ - significance.

Table 2. Statistics data for RFU of cell line NIH3T3 after exposure light of dose $1 \mathrm{~J} / \mathrm{cm}^{2}$.

\begin{tabular}{|c|c|c|c|}
\hline Photosensitizers & Concentration $(\mu \mathrm{mol} / \mathrm{L})$ & F (ANOVA) & Sig. $(P)$ \\
\hline Between TPPS $_{4}$, ZnTPPS, TMPyP & 0.5 & 12.820 & 0.005 \\
\hline Between TPPS $_{4}, Z^{4}{ }^{2} P_{4}^{4}$, TMPyP & 1 & 11.850 & 0.006 \\
\hline Between TPPS $_{4}, Z_{\text {nTPPS }}^{4}$, TMPyP & 5 & 18.012 & 0.005 \\
\hline Between TPPS $_{4}, Z^{2}$ TPPS $_{4}$, TMPyP & 10 & 47.780 & $<0.0001$ \\
\hline Between TPPS $_{4}$, ZnTPPS $_{4}$, TMPyP & 50 & 132.634 & $<0.0001$ \\
\hline Between $\mathrm{TPPS}_{4}, \mathrm{ZnTPPS}_{4}, \mathrm{TMPyP}$ & 100 & 216.305 & $<0.0001$ \\
\hline Photosensitizers & Concentration $(\mu \mathrm{mol} / \mathrm{L})$ & LSD Sig. $(P)$ & - \\
\hline $\begin{array}{l}\text { TPPS }_{4} \text { x ZnTPPS } \\
\text { TPPS }_{4} \text { x TMPyP } \\
\text { TMPyP x ZnTPPS }_{4}\end{array}$ & 0.5 & $\begin{array}{l}0.006 \\
0.005 \\
0.005\end{array}$ & - \\
\hline $\begin{array}{l}\mathrm{TPPS}_{4} \text { x ZnTPPS } \\
\text { TPPS }_{4} \text { x TMPyP } \\
\text { TMPyP x ZnTPPS }_{4}\end{array}$ & 1 & $\begin{array}{r}0.01 \\
0.01 \\
0.002\end{array}$ & - \\
\hline $\begin{array}{l}\mathrm{TPPS}_{4} \text { x ZnTPPS } \\
\text { TPPS }_{4} \text { x TMPyP } \\
\text { TMPyP x ZnTPPS }_{4}\end{array}$ & 5 & $\begin{array}{r}0.01 \\
0.001 \\
0.002\end{array}$ & - \\
\hline $\begin{array}{l}\mathrm{TPPS}_{4} \text { x ZnTPPS } \\
\text { TPPS }_{4} \text { x TMPyP } \\
\text { TMPyP x ZnTPPS }_{4}\end{array}$ & 10 & $\begin{array}{r}0.003 \\
0.001 \\
<0.0001\end{array}$ & - \\
\hline $\begin{array}{l}\mathrm{TPPS}_{4} \text { x ZnTPPS } \\
\text { TPPS }_{4} \text { x TMPyP } \\
\text { TMPyP x ZnTPPS }_{4}\end{array}$ & 50 & $\begin{array}{l}<0.0001 \\
<0.0001 \\
<0.0001\end{array}$ & - \\
\hline $\begin{array}{l}\text { TPPS }_{4} \text { x ZnTPPS } \\
\text { TPPS }_{4} \text { x TMPyP } \\
\text { TMPyP x ZnTPPS }_{4}\end{array}$ & 100 & $\begin{array}{r}<0.0001 \\
0.005 \\
<0.0001\end{array}$ & - \\
\hline
\end{tabular}

RFU - Relative Fluorescence Unit; F - test statistics; Sig. $(P)$ - significance.

of the impact of PDT on bacteria. During the last 10 years, advances in PDT have been were made: short time of antimicrobial therapy, possibility to use relatively low intensity, significant reduction of pathogens, broad spectrum of photosensitizers for treatment, lack of induced resistance after repetitive treatment and lack of mutagenicity ${ }^{17}$. Furthermore the advantages are that bacteria are eradicated in a short time, resistance is improbable and microflora are not disrupted ${ }^{17}$. This study reports the success of photodynamic therapy with photosensitizers ZnTPPS $_{4}$, TPPS 4 and TMPyP. All these photosensitisers were efficient on the NIH 3T3 cell line. The best results were achieved by TMPyP. This photosensitizer decreased the viability of the NIH 3 T3 cell line more than $85 \%$ (Fig. 1).

\section{CONCLUSION}

The goal of the present study was to test the efficiency of photosensitizers on the NIH 3T3 cell line and bacterial cells. Due to the rapid emergence of antibiotic resistance between pathogenic bacteria, the search for possible photosensitizer to resolve this problem is ongoing. Study of the effect of photodynamic therapy on the cell line was performed for comparison to bacterial strains. Our results 
Table 3. Statistics data for viability of S. aureus after exposure light of dose $0.5 \mathrm{~J} / \mathrm{cm}^{2}$.

\begin{tabular}{|c|c|c|c|}
\hline Photosensitizers & $\begin{array}{c}\text { Concentration } \\
(\mu \mathrm{mol} / \mathrm{L})\end{array}$ & F (ANOVA) & Sig. $(P)$ \\
\hline Between TPPS $_{4}$, ZnTPPS $_{4}$, TMPyP & 25 & 45.513 & $<0.0001$ \\
\hline Between $\mathrm{TPPS}_{4}, \mathrm{ZnTPPS}_{4}$, TMPyP & 50 & 79.421 & $<0.0001$ \\
\hline Between $\mathrm{TPPS}_{4}, \mathrm{ZnTPPS}_{4}, \mathrm{TMPyP}$ & 100 & 110.477 & $<0.0001$ \\
\hline Photosensitizers & $\begin{array}{c}\text { Concentration } \\
(\mu \mathrm{mol} / \mathrm{L})\end{array}$ & LSD Sig. $(P)$ & - \\
\hline $\begin{array}{l}\text { TPPS }_{4} \times \mathrm{ZnTPPS}_{4} \\
\text { TPPS }_{4} \times \mathrm{TMPyP} \\
\text { TMPyP x } \mathrm{ZnTPPS}_{4}\end{array}$ & 25 & $\begin{array}{l}<0.0001 \\
<0.0001 \\
<0.0001\end{array}$ & - \\
\hline $\begin{array}{l}\text { TPPS }_{4} \times \mathrm{ZnTPPS}_{4} \\
\text { TPPS }_{4} \text { x TMPyP } \\
\text { TMPyP x ZnTPPS }_{4}\end{array}$ & 50 & $\begin{array}{l}<0.0001 \\
<0.0001 \\
<0.0001\end{array}$ & - \\
\hline 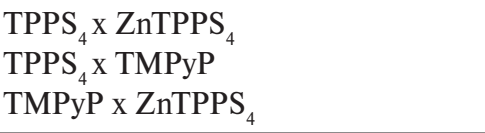 & 100 & $\begin{array}{c}0.02 \\
<0.0001 \\
<0.0001\end{array}$ & - \\
\hline
\end{tabular}

F - test statistics; Sig. $(P)$ - significance.

Table 4. Statistics data for viability of $P$. aeruginosa after exposure light of dose $0.5 \mathrm{~J} / \mathrm{cm}^{2}$.

\begin{tabular}{lccc}
\hline Photosensitizers & Concentration $(\mu \mathrm{mol} / \mathrm{L})$ & F $($ ANOVA $)$ & Sig. $(P)$ \\
\hline TMPyP & 50 & 72.447 & $<0.0001$ \\
& 25 & 99.906 & $<0.0001$ \\
& 12.5 & 22.844 & 0.00049 \\
& 6.25 & 12.820 & 0.005 \\
\hline
\end{tabular}

F - test statistics; Sig. $(P)$ - significance.

Table 5. Statistics data for viability of E. faecalis after exposure light of dose $0.5 \mathrm{~J} / \mathrm{cm}^{2}$.

\begin{tabular}{lccc}
\hline Photosensitizers & Concentration $(\mu \mathrm{mol} / \mathrm{L})$ & F (ANOVA) & Sig. $(P)$ \\
\hline TMPyP & 1.562 & 11.850 & 0.006 \\
\hline
\end{tabular}

F - test statistics; Sig. $(P)$ - significance.

\section{ABBREVIATIONS}

CM-H DCFDA, 5-(6-)-chloromethyl-2',7'-dichlorodihydrofluorescein diacetate; DMEM, Dulbecco's modified Eagle's medium; DMSO, Dimethyl sulfoxide; LEDs, Light emitting diodes; MTT, 3-(4,5-dimethythiazol-2-yl)-2,5-diphenyl tetrazolium-2H-tetrazolium bromide; NIH 3T3, Mouse embryonic fibroblast cell line; PACT, Photodynamic antimicrobial chemotherapy; PDT, Photodynamic therapy; ROS, Reactive oxygen species; TMPyP, 5,10,15,20-tetrakis(N-methylpyridinium-4-yl)porphyrin; TPPS 4 , Meso-tetra (4-sulfonatophenyl) porphyrin; ZnTPPS $_{4}$, Zinc-5,10,15,20-tetrakis(4-sulphonatophenyl) porphyrin.

\section{ACKNOWLEDGMENTS}

This work was supported by the grant project 2192/2011/G3 from the Ministry of Education, Youth and Sports of the Czech Republic, GACR 303/09/H048, CZ.1.05/2.1.00/01.0030 and LF_2011_009.

\section{REFERENCES}

1. Merchat M, Bertoloni G, Giacomini P, Villanueva A, Jori G, Mesosubstituted cationic porphyrins as efficient photosensitizers of gram-positive and gram-negative bacteria. J Photochem Photobiol B 1996:32:153-7.

2. Minnock A, Vernon DI, Schofield J, Griffiths J, Parish JH, Brown SB, Mechanism of uptake of a cationic water-soluble pyridium zinc phthalocyanine across the outer membrane of Escherichia Coli. Antimicrob. Agents Chemother 2000a;44:522-7.

3. Nitzan Y, Gutterman M, Malik Z, Ehrenberg B. Inactivation of gram - negative bacteria by photosensitized porphyrins. Photochem Photobiol 1992;55:89-97.

4. Maish T, Bosl C, Szeimies RM, Lehn N, Abels C. Photodynamic effects of novel XF porphyrin derivates on prokaryotic and eukaryotic cells. Antimicrob Agents Chemother 2005;49:1542-52.

5. Merchat M, Spikes JD, Bertoloni G, Jori G. Studies on the mechanism of bacteria photosensitization by meso-substitued cationic porphyrins. J Photochem Photobiol B 1996;35:149-57.

6. Minnock A, Vernon DI, Schofield J, Griffiths J, Parish JH, Brown ST. Photoinactivation of bacteria. Use of a cationic water-soluble zine 
phtalocyanine to photoinactivate both Gram-negative and Grampositive bacteria. J Photochem Photobiol B Biol 2000b;32:159-64.

7. Segalla A, Borsarelli CD, Braslavski SE, Spikes JD, Roncucci G, Dei D, Chiti G, Jori G, Reddi E. Photophysical, photochemical and antibacterial photosensitizing properties of a novel octacationic Zn(II)- phthalocyanine. Photochem Photobiol Sci 2002;1:641-8.

8. Raab O. Leber die Wirkung fluorizierender Stoffe auf Influsorien Z Biol 1990;39:524-46.

9. Chowdhary RK, Ratkay LG, Canaan AJ, Waterfield JD, Richter AM Levy JG. Uptake of Verteporfin ${ }^{\circledR}$ by Articular Tissues Following Systemic and Intra-Articular Administration. Biopharm. Drug Dispos 1998;19:395-400.

10. Lipson R, Baldes $E$, Olsen A. The use of a derivative of hematoporphyrin in tumor detection. JNCI 1961;26:1

11. Manyak MJ. Photodynamic therapy: present concepts and future applications. The Cancer Journal 1990;32:104-9.

12. Wainwright M. Photodynamic antimicrobial therapy (PACT). J Antimicrob Chemother 1998;42:13-28.
13. Nitzan $Y$, Shainberg B, Malik Z. The mechanism of photodynamic inactivation of Staphylococcus aureus by deuteroporphyrin. Curr Microbiol 1989;19:265-9.

14. Kolarova H, Nevrelova P, Tomankova K, Kolar P, Bajgar R and Mosinger J. Production of reactive oxygen species after photodynamic therapy by porphyrin sensitizers. Gen Physiol Biophys 2008;27:101-5

15. Kolarova H, Bajgar R, Tomankova K, Nevrelova P and Mosinger J. Comparison of sensitizers by detecting reactive oxygen species after photodynamic reaction in vitro. Toxicology in vitro 2007;21:1287-91.

16. Kolarova H, Mosinger J, Lenobel R, Kejlova K, Jirova D, Strnad M. In vitro toxicity testing of supramolecular sensitizers for photodynamic therapy. Toxicology In Vitro 2003; 17:775-8.

17. Jori G, Fabris C, Soncin M, Ferro S, Coppellotti O, Dei D, Fantetti L, Chiti G, Roncucci G. Photodynamic Therapy in the Treatment of Microbial Infections: Basic Principles and Perspective Applications. Lasers in Surgery and Medicine 2006;38:468-81. 